\title{
Effects of Mine Waste Contamination on Fish and Wildlife Habitat at Multiple Levels of Biological Organization in the Methow River
}

\section{Okanogan County, Washington}

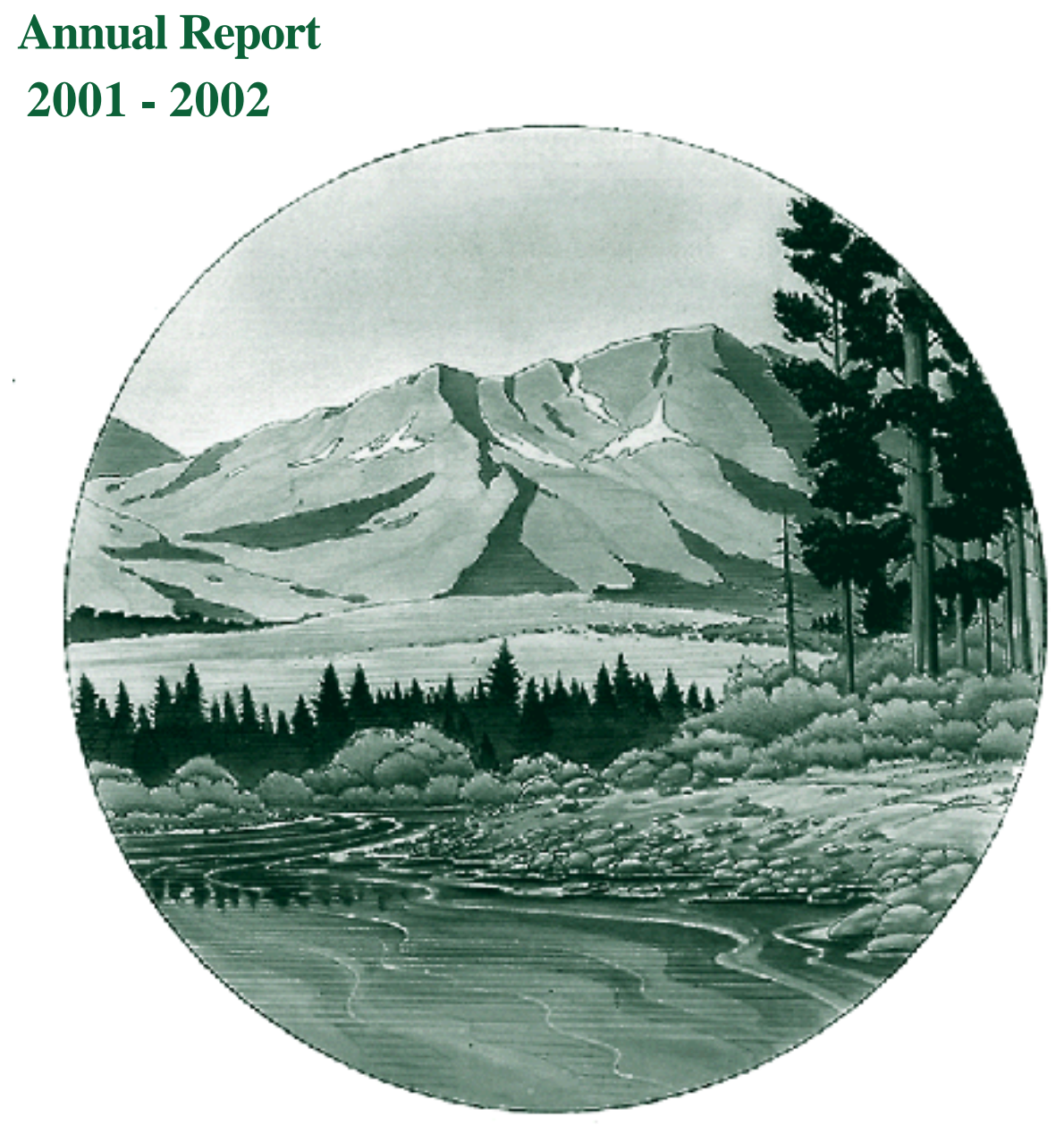

DOE/BP-00004710-2

June 2002 
This Document should be cited as follows:

Peplow, Dan, Robert Edmonds, "Effects of Mine Waste Contamination on Fish and Wildlife Habitat at Multiple Levels of Biological Organization in the Methow River",

Project No. 1998-03501, 34 electronic pages, (BPA Report DOE/BP-00004710-2)

\author{
Bonneville Power Administration \\ P.O. Box 3621 \\ Portland, Oregon 97208
}

This report was funded by the Bonneville Power Administration (BPA), U.S. Department of Energy, as part of BPA's program to protect, mitigate, and enhance fish and wildlife affected by the development and operation of hydroelectric facilities on the Columbia River and its tributaries. The views in this report are the author's and do not necessarily represent the views of BPA. 
The Effects of Mine Waste Contamination on Fish and Wildlife Habitat at Multiple Levels of Biological Organization, Methow River, Washington

\author{
Dan Peplow and Robert Edmonds
}

Annual Report (3/15/01 through 3/14/02)

BPA Project 98-035-01, Contract No. 00004710

(Performance Period: 3/15/00 - 3/14/03)

\author{
College of Forest Resources \\ University of Washington \\ Seattle, WA 98195
}

June 2002 


\section{TABLE OF CONTENTS}

$\begin{array}{lll}\text { I. } & \text { Abstract } & 3\end{array}$

II. Introduction 4

III. Summary of Past Year Activities and Highlights 5

IV. Study Area and Site Description 6

V. Study Design $\quad 8$

VI. Key Findings to Date $\quad 12$

$\begin{array}{ll}\text { VII. Discussion } & 15\end{array}$

$\begin{array}{ll}\text { VIII. Conclusion } & 18\end{array}$

$\begin{array}{ll}\text { IX. } & \text { References }\end{array}$

X. Expected Accomplishments for 3/15/2002 - 3/14/2003 22 


\section{ABSTRACT}

A three-year multidisciplinary study was conducted on the relationship between mine waste contamination and the effects on aquatic and terrestrial habitats in the Methow River below abandoned mines near Twisp in Okanogan County, Washington (U.S.A.). Ore deposits in the area were mined for gold, silver, copper and zinc until the early 1950's. An above-and-below-mine approach was used to study potentially impacted sites. Although the dissolved metal content of water in the Methow River was below the limits of detection, eleven chemicals of potential environmental concern were identified in the tailings, mine effluents, groundwater, streamwater and sediments (Al, As, B, Ba, Cd, Cr, Cu, Mn, Pb, Se and $\mathrm{Zn}$ ). The potential for ecosystem level impacts was reflected in the risk of contamination in the mine waste to communities and populations that are valued for their functional properties related to energy storage and nutrient cycling. Dissolved and sediment metal contamination changed the benthic insect community structure in a tributary of the Methow River below Alder Mine, and at the population level, caddisfly larval development in the Methow River was delayed. Arsenic accumulation in bear hair and $\mathrm{Cd}$ in fish liver suggest top predators are effected. In situ exposure of juvenile triploid trout (Oncorhynchus mykiss) to conditions at the downstream site resulted in reduced growth and increased mortality among exposed individuals. Histopathological studies of their tissues revealed extensive glycogen inclusions suggesting food is being converted into glycogen and stored in the liver but the glycogen is not being converted back normally into glucose for distribution to other tissues in the body. Subcellular observations revealed mitochondrial changes including a decrease in the number and increase in the size of electron-dense metrical granules, the presence of glycogen bodies in the cytoplasm, and glycogen nuclei in exposed trout hepatocytes, which are signs that Type IV Glycogen Storage disease is occurring. GSD IV is caused by either a deficiency or inactivation of the glycogen branching enzyme that results in the synthesis of an abnormal glycogen molecule hat is insoluble and has decreased branch points and increased chain length. These results show that the effects of mine waste contaminants can be expressed at all levels of organization from molecular to ecosystem-level responses. 


\section{INTRODUCTION}

The University of Washington, College of Forest Resources and the Center for Streamside Studies in Seattle, Washington, are being funded by the Bonneville Power Administration and the Northwest Power Planning Council (NWPPC) to conduct a three-year research project and measure the effects of contaminants released from the abandoned Alder Mill, Alder Mine and Red Shirt Mill, which are located in an upland area near the Methow River south of Twisp, in Okanogan County, Washington. The Northwest Power Planning Council was directed by act of Congress in 1980 to protect, mitigate and enhance fish and wildlife populations that have been affected by the construction and operation of hydroelectric dams. The current NWPPC Fish and Wildlife program recognized the potential impact of abandoned mines on fish habitat and linked the Endangered Species Act and the Clean Water Act by describing the kind of ecological change needed to improve the survival and productivity of diverse fish and wildlife populations.

Results we obtained from a preceding Bonneville Power Administration project, contract number 98BI-09396, revealed that acid mine drainage and waste-rock leachate from the Alder Mine site were impacting the water, substrates and benthic macroinvertebrates of Alder Creek, a tributary of the Methow River. We showed the chemical, biological, and physical characteristics of Alder Creek have been altered and that impacts were greatest where AMD entered Alder Creek and declined downstream from the zone due to dilution, precipitation, and sedimentation.

At the confluence of Alder Creek and the Methow River, where side channels serve as rearing habitats for juvinile salmonids including steelhead/rainbow (Salmo gairdneri) and Chinook salmon (Oncorhynchyus tshawtscha), water quality is considered to be good (Milton 1995). Although high concentrations of heavy metals are common in sediments even when they are undetectable in the water column (Dissmeyer 2000, USEPA 2000a), sediment quality in the Methow River has not been examined. Numerous stream sediment samples from widely dispersed sites in tributaries of the Methow River, including Alder Creek, have been analyzed for heavy metals as part of an assessment of mineral resource potential in the Okanogan National Forest (Grant 1982 and Boleneus and Chase 1999). While there are no state standards for metals in freshwater sediments, there are three sets of sediment guidelines adopted by the WDOE (Raforth et al., 2000) that can be used to evaluate the findings of the USFS study. Although the values for adverse effect can vary widely between the three guidelines, it appears that guidelines may be exceeded for $\mathrm{Zn}$ and $\mathrm{Cu}$ at six sites in the Alder Creek and Gold Creek watersheds, which are tributaries of the Methow River where numerous inactive mines are known to exist.

Under certain biogeochemical or physiological conditions, contaminated soil, groundwater and sediments can provide a long-term source of microelements that can be toxic to aquatic organisms. The purpose of this project is to (1) describe the pathway of heavy metal dispersion from their source to sediments in the Methow River, and 2) assess ecological risk along the exposure pathway at various levels of biological organization including ecosystem, community, population, individual, tissue, and cellular.

When concluded, this study will describe the processes responsible for the release of metals from small abandoned mine sites in an arid upland environment, their dispersal pathways, and their chemical and biological impacts on a large mainstem river. Based on these processes and pathways, specific remediation recommendations will be proposed. 


\section{SUMMARY OF PAST YEAR ACTIVITIES AND HIGHLIGHTS}

Field studies were started in March 2000 and laboratory analysis of chemical and biological samples began in September 2001. Data analysis and manuscript preparation also began in September 2001. Highlights of the performance periods from March 15, 2001 to March 14, 2002 are:

1. Submission of a manuscript on Health Risks Associated with Contamination of Groundwater by Abandoned Mines near Twisp in Okanogan County, Washington, to the Journal of Environmental Geochemistry and Health.

2. Prepared first draft of manuscript on the Chemical, Physical and Biological Effects of Mine Waste Contamination on a Headwater Stream in the North Cascade Mountains, Washington.

3. Prepared first draft of manuscript on Trace Element Release and Dispersion from SulfurBearing Mine Waste and the Contamination of Sediments in the Methow River, Okanogan County, Washington.

4. Began draft of manuscript on Ecosystem Level Effects of Contaminants from Abandoned Mine Waste near Twisp in Okanogan County, Washington.

5. Completed Above-and-below controlled trout exposure study and measured effects of exposure to contaminated sediments on growth and mortality among juvenile triploid trout.

6. Completed transmission electron microscopic (TEM) analysis of liver and kidney thin sections for mitochondrial biomarkers of exposure to metal contaminants. 


\section{STUDY AREA AND SITE DESCRIPTION}

The study site is located near the town of Twisp in Okanogan County, Washington (Figure 1). The Methow River basin is located in north central Washington east of the Cascade mountains and is bordered by Canada on the north. Draining nearly $4,662 \mathrm{~km}^{2}$, the Methow River flows southward through western Okanogan County and empties into the Columbia River at km 843 near the town of Pateros. The Methow watershed extends approximately $140 \mathrm{~km}$ from the confluence with the Columbia River to its headwaters located along the Cascade Crest and the Canadian border.

Topography within the Methow River basin ranges from mountainous terrain along the Cascade Crest to a gently sloping, wide valley found along the middle reaches. Elevation ranges from $2,600 \mathrm{~m}$ in the headwaters of the basin to approximately $240 \mathrm{~m}$ at the confluence of the Methow and Columbia Rivers. Soils in the valley consist of sandy loams that are underlain by alluvium and glacial outwash with very rapid permeability (Waitt 1972). The major groundwater aquifers of the Methow Valley exist in layers of unconsolidated sediments underlain by bedrock. Groundwater occurrence, movement and availability are primarily related to recharge sources and the configuration of depositional sediments.

The ore deposits that were mined for $\mathrm{Au}, \mathrm{Ag}, \mathrm{Cu}$ and $\mathrm{Zn}$ are composed largely of chemically precipitated silica in a 4.6-22.9 m wide zone of Cretaceous-Jurassic plutonic (intrusive) igneous stock (granite) in the Newby Group of volcanic rocks (Barksdale 1975). The Newby Group was intruded by the Alder Creek stock, which has been dated at $137 \pm 3$ m.y. (Burnet 1976; Bunning 1990). Ore minerals were deposited possibly during the emplacement of the Alder stock (Barksdale 1975). Carbonate rocks are found in the drainage basin and the streams and rivers are thus hardwater in nature. Alkalinity of the Methow River is $103 \pm 14 \mathrm{mg} \mathrm{L}^{-1}$ and the $\mathrm{pH}$ is $7.2 \pm$ 0.5, which is typical of a system dominated by bicarbonate (Stumm and Morgan, 1996).

The climate in the Methow Valley is within the Cascade Mountain rain shadow. Mean annual precipitation ranges from 25 to $38 \mathrm{~cm}$ and the mean annual temperature is below $10^{\circ} \mathrm{C}$ (USFS 1999). Precipitation is seasonal with roughly two-thirds occurring between October and March. Summers are generally hot and are characterized by extended dry periods. Precipitation increases in the fall and generally peaks in the winter with most precipitation in the basin occurring as snow between December and February. Since most of the precipitation occurs as snow, the seasonal distribution of runoff is strongly affected by snow storage.

Since streamflow in the basin is primarily driven by runoff from melting snow, flows exhibit a strong peak during spring and early summer with roughly 60 percent of the mean annual discharge occurring during May and June (Milhous 1976). Streamflow remains relatively high during July, but decreases substantially from August through October in response to a reduced snowpack, low precipitation, and decreased soil moisture. Stream flow in the Methow River reaches an annual low during late September and early October, with some sections going subsurface during dry years. Conversely, during wetter years, autumn precipitation may cause a slight increase in surface stream flows. Winter flows typically remain low in response to low autumn precipitation and freezing winter temperatures. Freezing temperatures retain moisture in the snow pack and freeze soil moisture. Brief warming trends in the winter months can melt snow or cause precipitation to fall as rain, slightly increasing stream flows. Runoff between years is also highly variable as reflected in streamflow data from USGS (1996). Maximum and minimum recorded or estimated flows for the Methow River at Twisp was 40,800 cfs (May 1948) and 134 cfs (September 1926), respectively. 


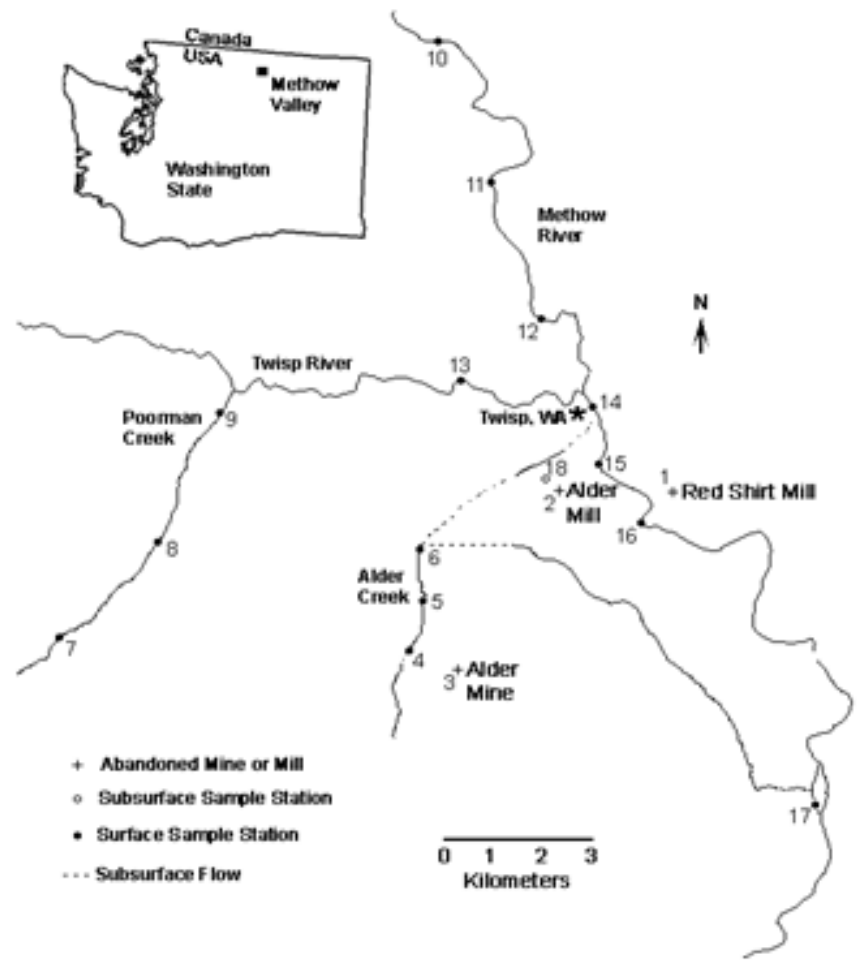

Figure 1. Methow River, Twisp River and Alder Creek near the town of Twisp in Okanogan County Washington (U.S.A.) with sample stations identified. Contaminant sources are at the Alder Mine, Alder Mill and Red Shirt Mill. 
This study was conducted in the center of what is referred to as the Middle Methow River Subwatershed by the Washington State Conservation Commission (WSCC 2000). The Middle Methow River Subwatershed extends from the confluence of the Chewuch River at Winthrop (RM 50.1) to the town of Carlton (RM 26.8). Spring Chinook, Summer Chinook, Steelhead/Rainbow and Bull Trout have been found to occur in this portion of the Methow River watershed and use includes migration, spawning and rearing (Figure $1 \mathrm{~b}$ ). When a survey was conducted by direct underwater observation (snorkeling) on September 4, 1998 to identify salmonids in Alder Creek (Peplow 1998) the species identified as present were native steelhead/rainbow trout (Salmo gairdneri) and Chinook salmon (Oncorhynchus tshawytscha). Two redds in the Methow River at the Red Shirt Mill were identified on 10/10/00 and 10/23/00. Two parr (presumably coho) were observed on 1/27/01 in the last pond on Alder Creek after ice melt and before water levels were sufficiently high to provide outlet.

Upper Columbia River summer steelhead, including the Methow river run, were listed under the Endangered Species Act (ESA) as "endangered" on August 18, 1997. Upper Columbia River spring Chinook salmon, including the Methow River run, were listed under the ESA as "Endangered" on March 16, 1999. Bull trout in the Methow River were listed under the ESA as "threatened" on June 10, 1998. Although not an ESA listed species, summer Chinook also spawn in the Methow River and have experienced a severe decline in numbers of returning adults. Summer Chinook are identified as "depressed" by the Washington Department of Fish and Wildlife. While it is clear that tributaries to the Methow River have been impaired by heavy metals from abandoned mine waste the impact of metals from historic mines on salmonid habitat in the Methow River has not been determined.

\section{Mine and Mill Site Descriptions}

The Alder Mine is located approximately $4.8 \mathrm{Km}$ southwest of Twisp (Figure 1). The site consists of at least three partially open adits (the north adit, the south adit, and an adit in the open pit), an adit retention pond, an open pit, and waste rock dumps. The site is on the north slope of a north-trending ridge. Slopes at the site range from 50-80\%. Estimates from aerial photographs indicate that waste rock covers over 15 hectares. The flow rate of drainage from the north adit ranges from $5-15 \mathrm{~L} \mathrm{~min}^{-1}$. South adit flow is seasonal and ranges from 0 to less than $5 \mathrm{~L} \mathrm{~min}^{-1}$.

The Alder Mill is located approximately $1 \mathrm{~km}$ south of Twisp, Washington, and approximately $500 \mathrm{~m}$ west of the Methow River and $63 \mathrm{~km}$ from the Columbia River. The Mill consists of two buildings, two tailings impoundments, and scattered waste rock and ore piles. The tailings impoundments are estimated to cover approximately 4 hectares of surface area. Inputs and springs supplied by Alder Creek feed the upper impoundment creating a contaminated wetlands environment. The phreatic surface in the upper tailings impoundment varies spatially and temporally between 0 and $4 \mathrm{~m}$ below the surface depending on time of year and snow melt.

The Red Shirt Mill is also located approximately $1 \mathrm{Km}$ south of Twisp and $63 \mathrm{Km}$ from the Columbia River but approximately 100 m east of the Methow River. The mill consists of a single building and a tailings pile. The tailings pile, which extends to the east bank of the Methow River, is estimated to cover 1 hectare of surface area. 

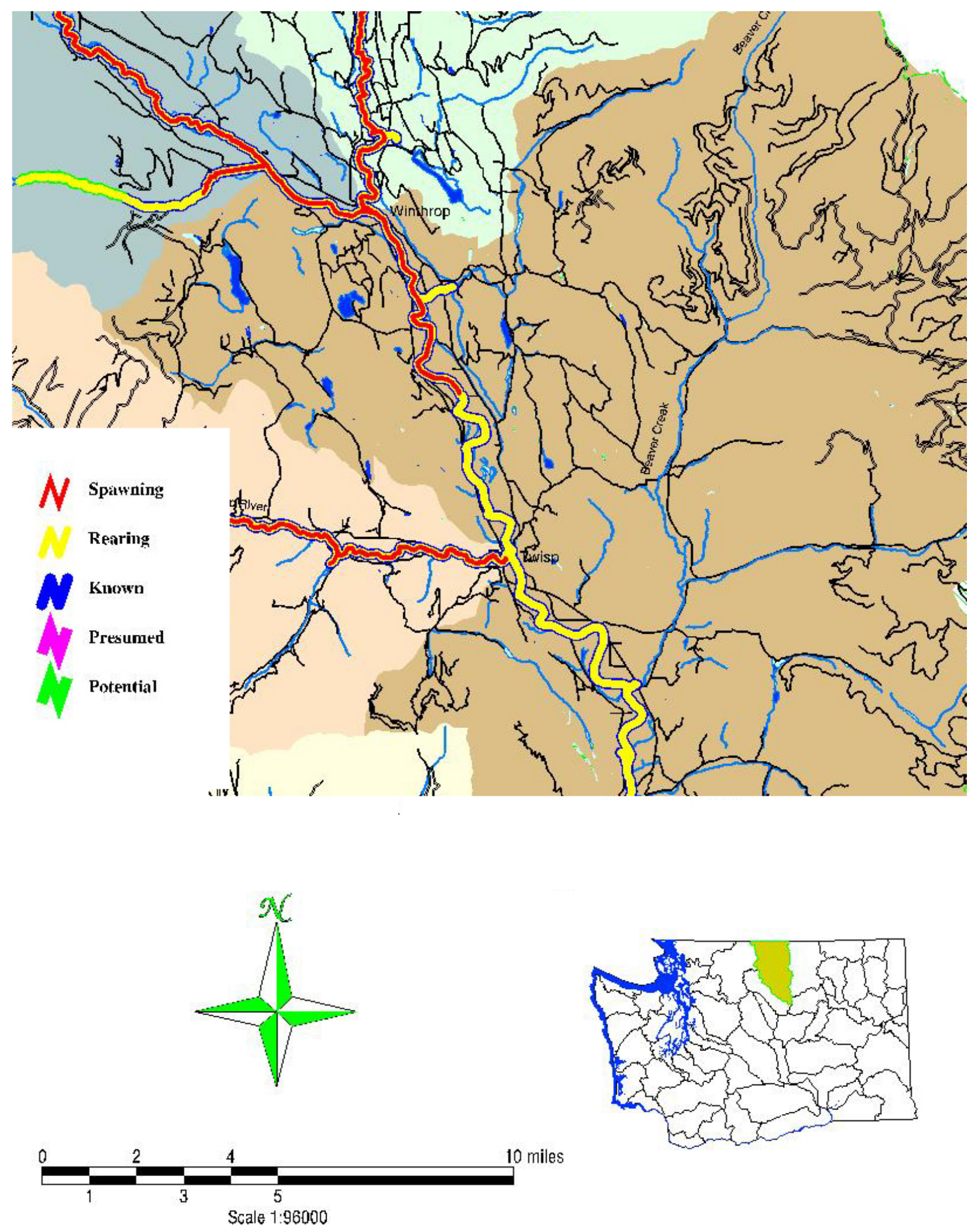

Figure 1b. Map of study area showing use of Middle Methow River Subwatershed by Spring Chinook, Summer Chinook, and Steelhead/Rainbow Trout (WSCC 2000). 


\section{V.STUDY DESIGN}

\section{$\underline{\text { Source }}$}

Ten domestic drinking water wells located adjacent to the Alder Mill, near Alder Creek below Alder Mine, and adjacent to the Red Shirt Mill, and two reference wells that were isolated from mine impacts (Figure 2) were sampled between October 1999 and June 2001. Samples of water from private domestic wells were collected from the well casing using disposable Teflon bailers in pre-cleaned $50-\mathrm{mL}$ polypropylene centrifuge tubes.

Sediment samples were collected using plastic scoops at a shallow depth $(<5 \mathrm{~cm})$ and immediately wet sieved in ambient water through a $63 \mu \mathrm{m}$ sieve. Samples were dried to constant weight at $90^{\circ} \mathrm{C}$. Water samples were collected in pre-cleaned teflon bottles. Subsamples were filtered (Gelman $0.45 \mu \mathrm{m}$, disposable $25 \mathrm{~mm}$ sterile disposable Acrodisc filter) and preserved to $\mathrm{pH}<2$ with $0.15 \%$ nitric acid and stored at less than $5^{\circ} \mathrm{C}$. All analyses were performed within 30 days of sample collection.

Samples of water and sediment were analyzed at the University of Washington, College of Forest Resources Analytical Laboratory in Seattle, Washington. Dissolved metal concentrations $(0.45 \mu \mathrm{m}$ filtered) were determined by ICP atomic emission spectrophotometry (ICP-AES; Thermo Jarrell Ash ICAP 61E). Samples were analyzed for As by Hydride Generated Atomic Fluorescence Spectrophotometry.

Chemicals of potential ecological concern (COPECs) were identified by comparing the concentrations of metals in tailings, AMD, groundwater, and sediments to ecotoxicological benchmarks, which were derived from primary literature by Suter and Mabrey (1994) for the exposure of aquatic life to chemicals in water, Hull and Suter (1994) for the exposure of benthic organisms to sediments, Will and Suter (1994) for the exposure of soil invertebrates and microbial communities, and by Opresko et al. (1994) for the exposure of wildlife to food, water, and soil.

\section{Ecosystem}

Figure 1 indicates the location of sampling stations for tailings, acid mine drainage (AMD), and Methow River Water and Sediments. A total of 34 grab samples were collected from the waste piles at the 3 mine sites. Sediments were sampled at each sample station along the mainstem of the Methow and Twisp Rivers. Four replicates of water and sediments were collected at each sample station (8-11) upstream from Twisp and the abandoned mine sites. Ten replicates of water and sediments were collected from each sample station (12-15) downstream from Twisp and the abandoned mine sites. Seven replicates of AMD were collected at station 1. All water and sediment sampling equipment was cleaned by washing with Liquinox ${ }^{\circledR}$ detergent and sequential rinses with distilled water, dilute nitric acid, and de-ionized water.

Samples of leaves from six aspen (Populus tremuloides) trees growing on the waste rock at the Alder Mine and samples of leaves from four aspen trees growing on the undisturbed slope on the opposite side of the watershed were collected. Aspen leaf miner larvae [Phyllocnistis populiella Cham. (Lepidoptera: Gracillaridae)] from aspen leaves were collected and pooled to make at least $0.5 \mathrm{~g}$ wet weight (80-100 larvae). Leaves were rinsed in deionized water, dried, ground and analyzed for metals by ICP-AES. Larvae were rinsed in deionized water, dried, ground and analyzed for metals by ICP-MS. Metal concentrations in leaves and larvae from the mine site 


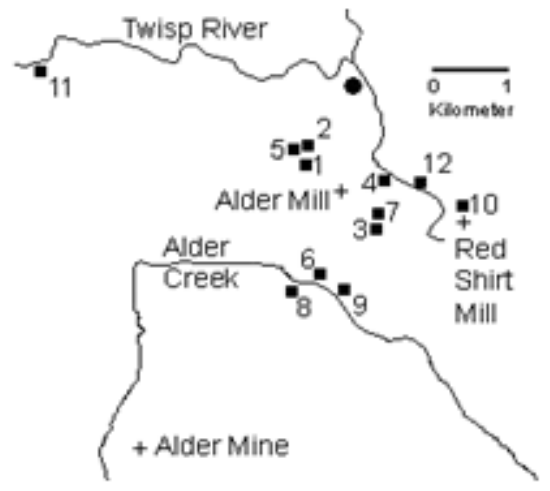

Figure 2. Location of private drinking water wells and locations where groundwater samples were collected in the vicinity of the contaminant sources at Alder Mine, Alder Mill and Red Shirt Mill. Reference wells number 11 and 12 are also identified. 
were compared to concentrations in the reference samples from trees that were not in contact with abandoned mine waste or its effluents.

The exposure of resident bear to As was determined using the bear hair capture technique and a non-consumable liquid lure. Scent attractant was placed on a log enclosed by a strand of barbed wire stretched approximately $50-\mathrm{cm}$ above the ground to snag hair. The use of this scent to attract bears to the hair ensured there was no possibility of food reward. Six samples of hair from a single station in the vicinity of the Alder Mine were collected for analysis over a two-year period between 2000 and 2001. Arsenic concentrations in hair were measured by Hydride Generated Atomic Fluorescence Spectrophotometry and compared to concentrations in reference samples from one male and one female bear, 10-years-old, that had been raised in captivity and fed controlled diets in an environment free of As.

Resident trout from a farm pond fed by water from Alder Creek (station 6), were euthanized by an overdose of MS-222 (0.1\%, pH 7.0) and intestine, gill, liver, and kidney were excised from three fish. Samples were assayed by ICP-AES for metals and results were compared to metal concentrations in tissue samples from fish in the Twisp River (station 13) that had not been exposed to mine waste.

\section{Community}

Surface water, sediment, and benthic macroinvertebrate samples were collected at stations along Alder and Poorman Creeks (Figure 1). Sample stations included three stations (4-6) on Alder Creek and Poorman Creek (7-9). Station 4 was located directly below mine outfall. Two stations (5 and 6) were spaced approximately $0.5 \mathrm{~km}$ apart below the mine. All chemical analyses for heavy metals were performed by ICP atomic emission spectrophotometry (Thermo Jarrell Ash ICAP 61E).

Biological assessments were accomplished using a $0.09 \mathrm{~m}^{2}$ Surber sampler $(15$ meshes $\mathrm{cm}^{-1}, 0.66 \mathrm{~mm} \mathrm{mesh}^{-1}$ ), and samples at the six sites (4-9) were collected in triplicate twice, once near high- and again near low-flow conditions (June and September 1998). Benthic invertebrate samples were collected from riffles in the same general vicinity as the water and sediment samples. At each of the sample sites, Surber samples were taken and sorted following standard procedures for the analysis of benthic macroinvertebrate community structure. Taxonomic identifications were made primarily using Merritt and Cummins (1996). Organisms were identified to genus except for Diptera, which were identified to the family level using a 7-65X stereoscope. Taxa richness and abundance were used to analyze data from Surber samples. Triplicate surface water and sediment samples were also collected at the same general locations and time as the Surber samples.

The students t-Test was used to compare the abundance of invertebrates in Alder Creek and Poorman Creek. The correlation of benthic invertebrate abundance, diversity and water and sediment metals concentrations with distance was evaluated by regression analysis. Statistical significance was computed using using SigmaPlot 2001, version 7.0 for Windows.

\section{$\underline{\text { Population }}$}

One hundred larvae from each of six sample sites located on opposing sides of the Methow River at sites (14-16) were collected and compared to one hundred larvae from each of four sample sites (10-13) upstream from the abandoned mine sites. Within one hour following collection, larva were transported to the laboratory, removed from their cases, blotted dry using 
Whatman \#40 filter paper to remove surface water, and weighed. After weighing, the larva were preserved in $70 \%$ ETOH. Head capsule widths were measured using a slide micrometer and a dissecting microscope. Instar groups and corresponding size ranges were identified based on a frequency distribution histogram of headcapsule width data, which were ranked in ascending order. Head capsules comprising the horizontal portions of graph were assumed to from the same instar groups and vertical portions of the graph were assumed to be transitions between instar groups. Size ranges for each instar group was set as the mid point of each transition range.

In this study, the risk of toxicity and carcinogenicity to humans from As in groundwater data was calculated based on its concentration in the water and on an estimate of water consumption rates. This study used the default drinking water intake rate of $2 \mathrm{~L} \mathrm{day}^{-1}$ for adults (70 kg body mass) (EPA 1980). To estimate the average daily dose (ADD), the daily water intake rate, assumed to be $2 \mathrm{~L} \mathrm{day}^{-1}$ was multiplied by the arithmetic mean concentration of the contaminant in well water, in $\mu \mathrm{g} \mathrm{L}^{-1}$, then divided by $70 \mathrm{~kg}$ for adults.

Exposure was expressed as a noncarcinogenic risk and as a carcinogenic risk. Noncarcinogenic risk was expressed in terms of the Hazard Quotient (HQ). The basic equation for calculating the noncarcinogenic HQ was to divide the ADD $\left(\mu \mathrm{g} \mathrm{kg-body-weight}{ }^{-1}\right.$ day $\left.^{-1}\right)$ by the chronic reference dose (RfD; $0.3 \mu \mathrm{g}$ As kg-body-weight ${ }^{-1}$ day $^{-1}$ ) (Calow 1998, IRIS 2001). Carcinogenic risks associated with As were statements of probability and were calculated by multiplying the ADD by a Cancer Slope Factor (CSF, $1 / 1500 \mu \mathrm{g} \mathrm{kg}^{-1} \mathrm{day}^{-1}$ ) (Calow 1998, IRIS 2001).

\section{Individual}

Eighty-four hatchery-raised triploid trout (Oncorhynchus mykiss, $<35 \mathrm{~g}$ ) were transferred from a nearby hatchery (Trout Lodge, Quincy, WA) and equally divided into two pens approximately $1 \mathrm{~m}$ on a side. Fish pens were constructed from aquaculture netting on a PVC pipe frame. One pen was located in a Methow River side channel downstream from the abandoned mine site (station 17) and the other pen was located upstream from the abandoned mine sites (station 13). Fish, maintained in the pens from 5/7/01 to 6/11/01, were fed (Rangen 3/32 EXTR 400 Slow Sink food \#4974) once daily in the morning (7:00-8:00) at 4\% of their body weight day $^{-1}$. Visual examination during feeding revealed that the fish readily ingested the food provided and were satiated daily. Each pen was monitored daily for morbidity and mortality throughout the exposure period. At the end of exposure, fish were euthanized $(0.1 \% \mathrm{MS}-222, \mathrm{pH}$ 7) weighed and their final body weights measured. Temperature, dissolved oxygen and alkalinity were also measured daily at each site using Hobo model H8 temperature data loggers, A YSI model 85 meter was employed for the measurement of dissolved-oxygen (DO), total dissolved solids (TDS) and temperature. Alkalinity was measured in the field using the LaMotte Direct Read Titration Kit (Model 221780). A Piccolo Model HI 1295 temperature compensated digital meter was used to measure $\mathrm{pH}$. Conductivity, $\mathrm{pH}$ and $\mathrm{DO}$ were standardized daily before and after use. Current velocity was measured following the method described by Hauer and Lamberti (1996). The students t-Test was used to compare average weight of fish from pen above and below the abundance of invertebrates in Alder Creek and Poorman Creek. Statistical significance was computed using using SigmaPlot 2001, version 7.0 for Windows.

Tissue and Cell: Liver samples were excised from five fish per pen at the end of the exposure period. Samples less than $2 \mathrm{~mm}$ in diameter were fixed for 12 hours at $4^{\circ} \mathrm{C}$ in Karnovsky's fixative (5\% gluteraldehyde and 4\% formaldehyde in $0.1 \mathrm{M}$ cacodylate buffer). Materials were then transferred to $0.1 \mathrm{M}$ sodium-cacodylate buffer and stored at $4{ }^{\circ} \mathrm{C}$ until transfer to the histopathology laboratory at the University of Washington, Department of Health Sciences. 
Tissue samples were then dehydrated in a series of alcohol and embedded in Eponate. Ultrathin sections obtained with a Reichert/Jung Ultra-cut E microtome were collected on copper grids, contrasted with uranyl acetate and lead citrate. Duplicate samples not contrasted with uranyl acetate and lead citrate were also prepared to control for the effects of staining on the presence of electron-dense granules in mitochondria. Specimens were observed with a Phillips CM 100 transmission electron microscope (TEM). 


\section{KEY FINDINGS TO DATE}

\section{Ecosystem}

Table 1 lists median concentrations of the eleven inorganic elements that were identified as chemicals of potential environmental concern (COPECs) based on the comparison of their concentrations in tailings, AMD, groundwater, and sediments from the nearby Methow River to benchmarks for aquatic and terrestrial microbes, plants, animals, and estimated background concentrations. All eleven elements were COPECs in the tailings, but the number of COPECs in AMD, groundwater and Methow River sediments declined to 4, 2 and 3 respectively.

Since the concentration of COPECs would be relatively constant over time in tailings and because plants, earthworms, and microbes are immobile, no averaging over time was necessary. Also, since the maximum element concentration in tailings would imply that at least some organisms are at risk, when the median element concentrations exceed benchmark values as they do in this study it would be reasonable to expect that most organisms at the site would be exposed to potentially toxic levels of the element. Table 2 shows five of the COPECs, Al, B, Cd, Mn, and $\mathrm{Zn}$, were accumulated in aspen leaves from sites contaminated with tailings and that these elements became magnified in aspen leaf miner larvae that fed on the contaminated leaves.

Terrestrial wildlife average their exposure to inorganic contaminants in AMD as they move across a range. Aquatic organisms also average their exposures over time in water where the concentration of dissolved contaminants varies seasonally. Three COPECs, Cd, Mn, and Zn were also were also found accumulating in triploid trout gill samples (Table 2), Cd was elevated in trout liver samples and As was found accumulating in the hair collected from black bears in the vicinity of the Alder Mine.

\section{Community}

The species composition in contaminated Alder Creek was distinctly different from reference stations along Poorman Creek. Forty-eight taxa were identified in this study. A comparison of the community structure of the Poorman Creek reference stations to that of Alder Creek, including the 34 most abundant taxa, is given in Figure 3. The number of taxa and abundance of macroinvertebrates was less in Alder Creek stations 4-6 than in Poorman Creek reference stations 7-9. Abundance in Alder Creek recovered from its minimum at station 4 to levels that were similar to the downstream levels in Poorman Creek at station $6(n=6, r=0.95$, $\mathrm{p}<0.05)$. A similar trend for taxa richness in Alder Creek revealed an increase with distance downstream from mine outfall $(n=6, r=0.95, p<0.05)$.

Baetis, Cinygmula, Chloroperlidae, Heterlimnius, and Chironomidae, the dominant taxa based on overall abundance, could be found at all sites in the reference stream (Poorman Creek) although not always in the same order. Of the dominant taxa in Poorman Creek, Baetis, Chloroperlidae, Heterlimnius, and Chironomidae were reduced by at least 50\% in Alder Creek. Cinygmula was the second most abundant taxa in Poorman Creek and in Alder Creek it was the second least abundant. Out of the 48 taxa found in Poorman Creek, 17 taxa (35\%) were absent from Alder Creek. Simulidae, which occurred infrequently in Poorman creek, was the dominant taxa in Alder Creek.

For all stations in Alder Creek, 10 taxa (i.e., Baetis, Pelecorhynchidae, Amphinemura, Zapada, Heterlimius, Simulidae, Chironomidae, Gammaridae, Polypectropus, Ryacophila) accounted for $80 \%$ of the total individuals, which is similar to reference stations 7-9 in which 11 
Table 1. Chemicals of Potential Environmental Concern

\begin{tabular}{|c|c|c|c|c|c|c|c|c|c|c|c|c|}
\hline \multirow[b]{2}{*}{ Chemical } & \multicolumn{4}{|c|}{ Tailings $\left(\mathrm{mg} \mathrm{Kg}^{-1}\right)$} & \multicolumn{2}{|c|}{ AMD Station $3\left(\mathrm{mg} \mathrm{L}^{-1}\right)$} & \multicolumn{3}{|c|}{ Groundwater $\left(\mu \mathrm{g} \mathrm{L}^{-1}\right)$} & \multicolumn{3}{|c|}{ Methow River Sediments $\left(\mathrm{mg} \mathrm{Kg}^{-1}\right)$} \\
\hline & $\begin{array}{c}\text { Median } \\
\text { Concnetration } \\
\text { Tailings } \\
\end{array}$ & $\begin{array}{c}\text { Plant } \\
\text { Benchmark }\end{array}$ & $\begin{array}{l}\text { Earthworm } \\
\text { Benchmark }\end{array}$ & $\begin{array}{c}\text { Microbial } \\
\text { Benchmark }\end{array}$ & $\begin{array}{c}\text { Median } \\
\text { Concnetration } \\
\text { AMD }\end{array}$ & $\begin{array}{c}\text { Wildlife } \\
\text { Benchmark }\end{array}$ & $\begin{array}{c}\text { Median } \\
\text { Concentration } \\
\text { Groundwater }\end{array}$ & $\begin{array}{c}\text { Median } \\
\text { Concentration } \\
\text { Background }\end{array}$ & $\begin{array}{c}\text { Groundwater } \\
\text { Criteria }\end{array}$ & $\begin{array}{c}\text { Median } \\
\text { Concentration } \\
\text { Sediment }\end{array}$ & $\begin{array}{c}\text { Median } \\
\text { Concentration } \\
\text { Background } \\
\end{array}$ & $\begin{array}{l}\text { Aquatic } \\
\text { Biota } \\
\text { Bencmark }\end{array}$ \\
\hline $\mathrm{Al}$ & 5161 & 50 & & 600 & & & & & & & & \\
\hline As & 90 & 10 & 60 & & 0.2 & $0.16^{1}$ & 12 & 0 & 0.05 & & & \\
\hline B & 61 & 0.5 & & 20 & & & & & & & & \\
\hline $\mathrm{Ba}$ & 1405 & 500 & & & & & & & & 133 & 0 & 20 \\
\hline $\mathrm{Cd}$ & 9 & 4 & & & 2.8 & $1.89^{2}$ & & & & & & \\
\hline $\mathrm{Cr}$ & 6 & 1 & 0.4 & & & & & & & & & \\
\hline $\mathrm{Cu}$ & 336 & 100 & 50 & 100 & & & & & & 120 & 170 & 34 \\
\hline $\mathrm{Mn}$ & 110 & & & 100 & & & & & & 580 & 22 & 460 \\
\hline $\mathrm{Pb}$ & 133 & 50 & & & & & & & & & & \\
\hline $\mathrm{Se}$ & 512 & 1 & 70 & 100 & 1.2 & $0.74^{3}$ & 30 & 0 & 10 & & & \\
\hline $\mathrm{Zn}$ & 264 & 50 & 200 & 100 & 203.8 & $52.20^{4}$ & & & & & & \\
\hline
\end{tabular}

'Whitetail Deer

${ }^{2}$ Cd-salt. Short-tailed shrew, Little Brown Bat, White-footed Mouse, Meadow Vole, Cottontail Rabbit, Mink, Red Fox, Whitetail Deer

${ }^{3}$ Selanate: Short-tailed shrew, Little Brown Bat, White-footed Mouse, Meadow Vole, Cottontail Rabbit, Mink, Red Fox, Whitetail Deer

${ }^{4}$ Zinc Carbonate: American Robin, American Woodcock, Wild Turkey, Belted Kingfisher, Great Blue Heron, Barred Owl, Barn Owl, Cooper's Hawk, Red-tailed hawk 
Table 2. Accumulation of COPECs in aquatic and terrestrial plant and animal tissue

\begin{tabular}{|c|c|c|c|c|c|c|c|c|c|c|}
\hline & & $\begin{array}{c}\text { Aspen } \\
\text { Leaves }\end{array}$ & $\begin{array}{c}\text { Samples } \\
n=\end{array}$ & $\begin{array}{c}\text { Aspen Leaf Miner } \\
\text { Larvae }>100 \\
\text { larvae per } 0.5 \mathrm{~g} \\
\text { sample }\end{array}$ & Bear Hair & $\begin{array}{c}\text { Samples } \\
n=\end{array}$ & $\begin{array}{c}\text { Triploid } \\
\text { Trout Liver }\end{array}$ & $\begin{array}{c}\text { Samples } \\
n=\end{array}$ & $\begin{array}{l}\text { Triploid } \\
\text { Trout Gills }\end{array}$ & $\begin{array}{c}\text { Samples } \\
n=\end{array}$ \\
\hline $\mathrm{Al}$ & $\begin{array}{c}\text { Unexposed } \\
\text { Exposed }\end{array}$ & $\begin{array}{c}14 \pm 11 \\
46 \pm 15^{*}\end{array}$ & $\begin{array}{l}4 \\
6\end{array}$ & $\begin{array}{l}522 \\
3480\end{array}$ & & & & & & \\
\hline As & $\begin{array}{l}\text { Unexposed } \\
\text { Exposed }\end{array}$ & & & & $\begin{array}{l}0.05 \pm 0.01 \\
0.89 \pm 0.50^{*}\end{array}$ & $\begin{array}{l}2 \\
6\end{array}$ & & & & \\
\hline B & $\begin{array}{c}\text { Unexposed } \\
\text { Exposed }\end{array}$ & $\begin{array}{c}33 \pm 6 \\
94 \pm 42^{*}\end{array}$ & $\begin{array}{l}4 \\
6\end{array}$ & & & & & & & \\
\hline $\mathrm{Ba}$ & $\begin{array}{l}\text { Unexposed } \\
\text { Exposed }\end{array}$ & & & $\begin{array}{l}10.3 \\
51.8\end{array}$ & & & & & & \\
\hline $\mathrm{Cd}$ & $\begin{array}{c}\text { Unexposed } \\
\text { Exposed }\end{array}$ & $\begin{array}{c}<0.9 \\
23 \pm 21^{*}\end{array}$ & $\begin{array}{l}4 \\
6\end{array}$ & $\begin{array}{l}6.0 \\
102\end{array}$ & & & $\begin{array}{c}<0.6 \\
11 \pm 2^{*}\end{array}$ & $\begin{array}{l}3 \\
3\end{array}$ & $\begin{array}{c}0.0 \\
13 \pm 5^{*}\end{array}$ & $\begin{array}{l}3 \\
3\end{array}$ \\
\hline $\mathrm{Cu}$ & $\begin{array}{l}\text { Unexposed } \\
\text { Exposed }\end{array}$ & $\begin{array}{l}10 \pm 1 \\
15 \pm 7\end{array}$ & $\begin{array}{l}4 \\
6\end{array}$ & $\begin{array}{l}26.0 \\
261\end{array}$ & & & & & & \\
\hline $\mathrm{Mn}$ & $\begin{array}{c}\text { Unexposed } \\
\text { Exposed }\end{array}$ & $\begin{array}{c}78 \pm 9 \\
104 \pm 18^{*}\end{array}$ & $\begin{array}{l}4 \\
6\end{array}$ & $\begin{array}{l}22.4 \\
57.1\end{array}$ & & & & & $\begin{array}{c}9 \pm 6 \\
12 \pm 2\end{array}$ & $\begin{array}{l}3 \\
3\end{array}$ \\
\hline $\mathrm{Pb}$ & $\begin{array}{l}\text { Unexposed } \\
\text { Exposed }\end{array}$ & $\begin{array}{l}2 \pm 1 \\
3 \pm 3\end{array}$ & $\begin{array}{l}4 \\
6\end{array}$ & $\begin{array}{l}1.2 \\
14.4\end{array}$ & & & & & & \\
\hline $\mathrm{Se}$ & $\begin{array}{c}\text { Unexposed } \\
\text { Exposed }\end{array}$ & $\begin{array}{c}3 \pm 0 \\
12 \pm 11\end{array}$ & $\begin{array}{l}4 \\
6\end{array}$ & & & & & & & \\
\hline $\mathrm{Zn}$ & $\begin{array}{c}\text { Unexposed } \\
\text { Exposed }\end{array}$ & $\begin{array}{c}150 \pm 15 \\
610 \pm 212^{*}\end{array}$ & $\begin{array}{l}4 \\
6\end{array}$ & $\begin{array}{l}255 \\
1050\end{array}$ & & & & & $\begin{array}{c}93 \pm 22 \\
486 \pm 104^{*}\end{array}$ & $\begin{array}{l}3 \\
3\end{array}$ \\
\hline
\end{tabular}

Data are means \pm SD for samples from contaminated and reference sites ${ }^{*} P<0.05$ vs reference samples by $\mathrm{t}$-test 




Figure 3. Abundance of benthic macroinvertebrate taxa in the Poorman Creek at stations 7-9 and in the stream below Alder mine at stations 4-6 are shown to illustrate the impacts of mine waste contamination on invertebrate community structure. Three samples were collected in June and September at each sample site using a Surber were collected using a $0.09 \mathrm{~m} 2$ Surber sampler (15 meshes $\mathrm{cm}-1,0.66 \mathrm{~mm}$ mesh-1). 
taxa comprised $80 \%$ of the total individuals sampled (i.e., Baetis, Cinygmula, Haploperla, Heterlimnius, Ephemerella, Pseudocloeon, Chironomidae, Yoraperla, Rhyacophila, Parapsyche, and Psychodidae ). At station 4, below mine outfall, the invertebrate community was dominated by 5 taxa, Simulidae, Baetis, Zapada, Heterlimnius, and Malenka, which accounted for $80 \%$ of the individuals. At station 6 , six taxa comprised $80 \%$ of total individuals identified including Simulidae, Heterlimnus, Amphinemura, Limnocharidae, Gammarus, and Zapada.

\section{$\underline{\text { Population }}$}

The mean live body weight of caddisfly larvae (Ecclesiomia spp.) was lower in the Methow River below the mine sites (stations 14-16) than it was upstream at stations 10-13 [2.3 \pm 0.5 (SD) vs. $1.2 \pm 0.2$ g 100-larvae $\left.{ }^{-1}, P<0.02\right]$. Growth patterns were also different between exposed larvae (stations 14-16), which were comprised of five larval stages and reference larvae (stations 10-13), which were comprised of seven larval stages. Development of the exposed larvae lagged the reference larvae (Figure 4$)$, which were comprised mostly of $4^{\text {th }}$ instar larvae (84\%) and only $8 \%$ were $5^{\text {th }}$ instar. The reference larvae were comprised of fewer $4^{\text {th }}$ instar $(63 \%)$ and more $5^{\text {th }}$ instar (35\%) larvae.

The average As concentration in water samples taken between October 1999 and June 2001 from ten domestic drinking water wells located adjacent to Alder Mill, near Alder Creek below Alder Mine, and adjacent to the Red Shirt Mill ranged from $<1-298 \mu \mathrm{g} \mathrm{L}^{-1}$. The calculated average daily dose (ADD) for As ranged from $<0.029-8.5 \mu \mathrm{g} \mathrm{kg}^{-1} \mathrm{day}^{-1}$. The noncarcinogenic HQ for humans drinking water from wells 1-10 ranged from a high of 28.3-1.7, which places them above a threshold of concern for adverse health effects. Carcinogenic risk estimates were also high. On average, one excess death from cancer per 909 adults (1.1E-03) is expected to develop at the 95 percent confidence limit for all wells tested. Carcinogenic risk from drinking water from well 1 was 1-in-77 for adults. Two reference wells were also sampled and no As was detected in either of the ten samples from well 11 or the 11 samples from well 12.

$\underline{\text { Individual }}$

The mean body weight of trout in the exposed group dowstream from the abandoned mines (station 17) was less than the body weights of the upstream control group (station 13) $[65 \mathrm{~g} \pm 10$ (SD) vs. $71 \pm 9, P<0.01]$. Mortality among the trout in the test group downstream from the abandoned mines also exceeded the upstream control group. Three fish died within 96 hours following the beginning of exposure compared to no deaths in the control group. Two dead indigenous Coho parr were also encountered at station 17 during the study period. No other deaths were observed during this study.

With the exception of sediment metals concentrations (Table 1), water quality appeared adequate for use by even the most sensitive freshwater biota. Maximum temperatures were less than $16^{\circ} \mathrm{C}$, the freshwater criteria for class A (excellent) surface water in the State of Washington (Ecology 1992) and pH ranged from 7.3 - 8.6. Alkalinity exceeded $190 \mathrm{mg} \mathrm{L}^{-1}$ as $\mathrm{CaCO}_{3}$ causes the streams to have a naturally high buffering capacity. Dissolved oxygen exceeded $8.3 \mathrm{mg} \mathrm{L}^{-1}$ at all stations, which exceeded $8.0 \mathrm{mg} \mathrm{L}^{-1}$, the freshwater criteria for class A (excellent) surface water.

$\underline{\text { Tissue }}$

TEM microscopic examination of liver sections reveal large glycogen stores in the hepatocytes of trout in the group exposed to conditions downstream from mines compared to upstream samples (Figure 5). Upstream, hepatocytes appeared normal with no evidence of 


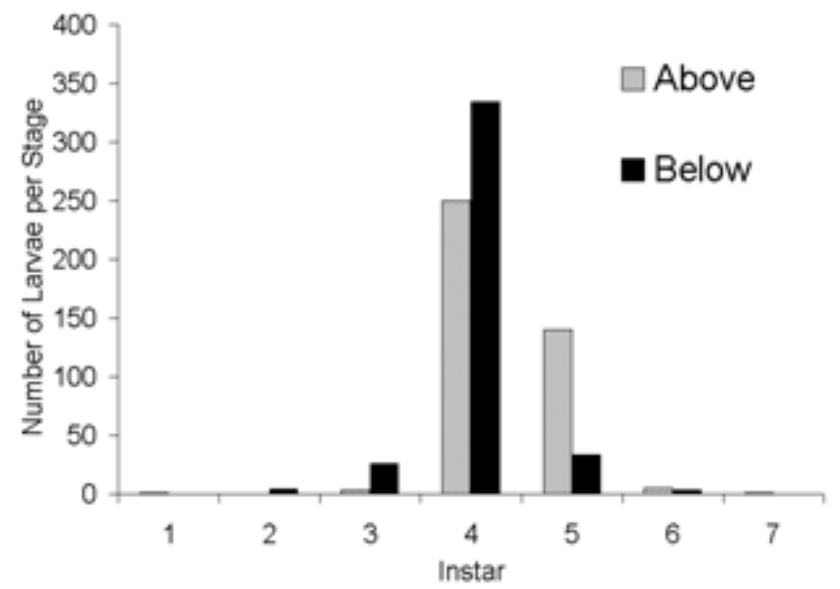

Figure 4. Number of larvae per instar stage for the caddisfly Ecclesiomyia spp.. One hundred larvae from each of six sample sites located on opposing sides of the Methow River at sites (14-16) were collected and compared to one hundred larvae from each of four sample sites (10-13) upstream from the abandoned mine sites. 

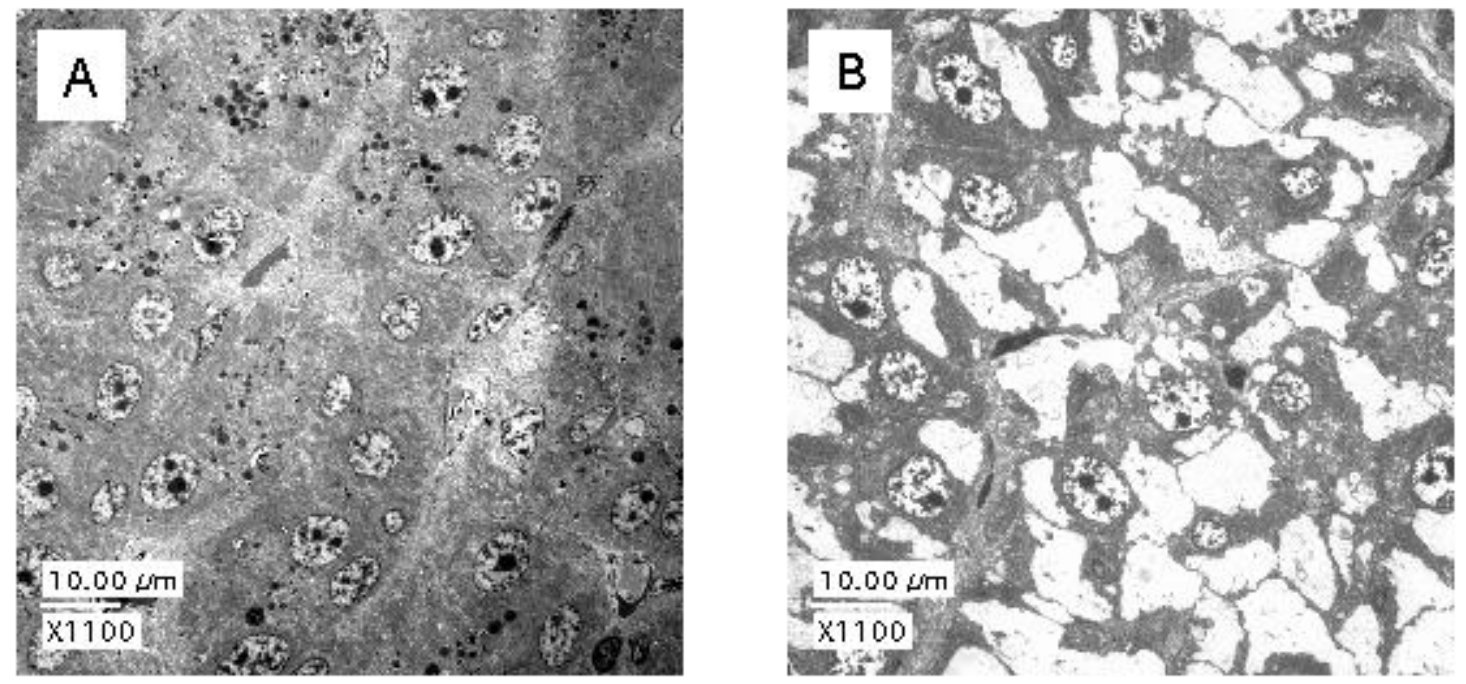

Figure 5. TEM micrographs of livers sections from juvenile triploid trout (Oncorhynchus mykiss) [fixed in Karnovsky's (5\% gluteraldehyde and 4\% formaldehyde in $0.1 \mathrm{M}$ cadodylate buffer), embedded in Eponate, contrasted with uranyle acetate and lead citrate. $(A)$ hepatocytes from reference trout maintained 7 -weeks in pens upstream from the abandoned mine sites (station 13), (B) hepatocytes from trout maintained 7-weeks in pens and exposed to ambient conditions in a Methow River side channel downstream from the abandoned mine site (station 17). 
abnormal glycogen metabolism. The changes observed seem similar to the glycogen storage diseases (GSD) in which metabolic disorders can lead to the accumulation of glycogen (Phillips et al. 1987).

\section{$\underline{\text { Cell }}$}

TEM microscopic examination of liver sections also revealed glycogen bodies in the nuclei and cytoplasm of hepatocytes in trout from the pen downstream from the mine sites (Figure 6) suggesting a disorder in Cu metabolism similar to Wilson's disease might be occurring (Phillips et al. 1987). Large, electron-dense granules in the matrix of trout hepatocyte mitochondria were also observed (Figure 7). 

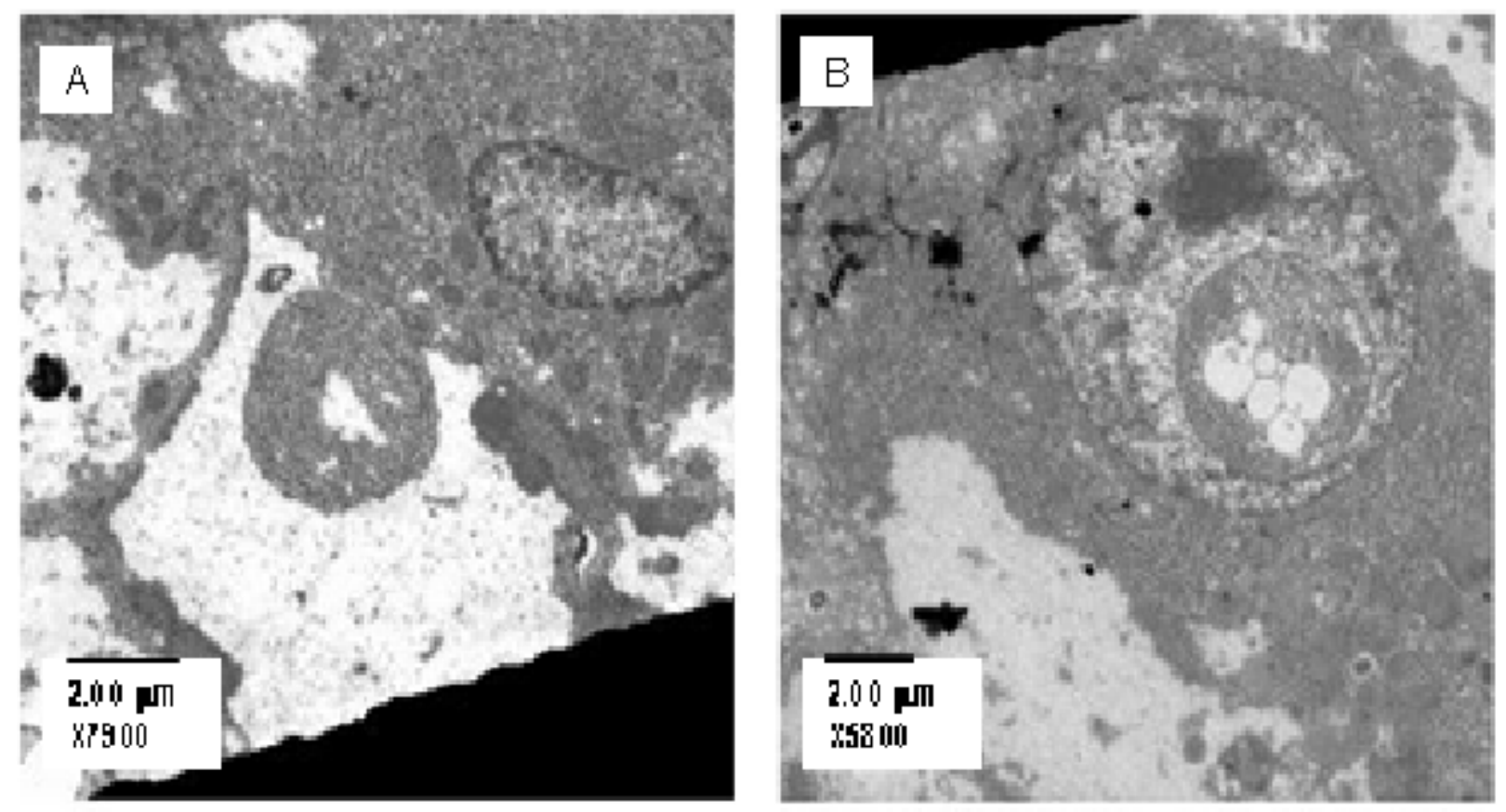

Figure 6. TEM micrographs of hepatocyte from juvenile triploid trout (Oncorhynchus mykiss) maintained 7-weeks in pens and exposed to ambient conditions in a Methow River side channel downstream from the abandoned mine site (station 17) [fixed in Karnovsky's ( $5 \%$ gluteraldehyde and $4 \%$ formaldehyde in $0.1 \mathrm{M}$ cadodylate buffer), embedded in Eponate, contrasted with uranyle acetate and lead citrate. (A) glycogen body in hepatocyte cytoplasm, (B) glycogen nucleus. 



Figure 7. TEM micrographs of mitochondria in hepatocytes from juvenile triploid trout (Oncorhynchus mykiss) [fixed in Karnovsky's (5\% gluteraldehyde and $4 \%$ formaldehyde in $0.1 \mathrm{M}$ cadodylate buffer), embedded in Eponate, and contrasted with uranyle acetate and lead citrate. Duplicate samples not contrasted with uranyl acetate and lead citrate were also prepared to control for the effects of staining on the presence of electron-dense granules in mitochondria. (A) stained sections from trout maintained 7-weeks in pens upstream from the abandoned mine sites (station 13), (B) unstained sections from trout maintained 7-weeks in pens upstream from the abandoned mine sites (station 13), (C) stained sections from trout maintained 7-weeks in pens downstream from the abandoned mine sites (station 17), and (D) stained sections from trout maintained 7 -weeks in pens downstream from the abandoned mine sites (station 17). 


\section{DISCUSSION}

In this study we showed that there were 11 COPECs and that their effects can be expressed at any level of organization. Potential sources of these contaminants were waste rock deposited on the surface of three abandoned mine and mill sites near Alder Creek and the Methow River that contain naturally occurring elements at levels that exceed tolerance levels of biota at the site, leachate containing contaminants produced by the chemical and biological oxidation of metal sulfide waste and mobilized by infiltrating water from precipitation, and contaminated effluent from three mine adits.

Migration pathways of greatest interest are surface water and shallow groundwater. According to the infiltration theory of runoff, precipitation on a hillslope will be absorbed if the intensity is less than the infiltration capacity. If inputs exceed the infiltration capacity then overland flow is produced. Due to the high permeability of soils in the study area and because precipitation is low, subsurface flow is assumed to be the dominant process. Runoff waters carry dissolved, colloidal and suspended contaminants from hillslopes. Likely pathways of transport from source to surface water includes ARD and AMD leachates are mixed with shallow groundwater that emerge as seeps and enter streams through gaining reaches.

In the forested areas where gangue material was deposited, the risk of COPECs to microbial and earthworm populations suggest that ecosystem properties are at risk because these are ecosystem components that are valued more for their functional properties than they are for their community or population properties. Earthworms are probably the most important invertebrates in promoting soil fertility (Killham 1994). Their feeding and burrowing activities break down organic matter and release nutrients and improve aeration, drainage, and reduce soil aggregation. Earthworms are also important components of the diets of many higher animals.

Soil microbes are also important in regards to nutrient cycling (Killham 1994). They are primary consumers of soil organic matter, convert nutrients into plant-available forms, and serve as a food source for higher trophic levels. Metal contamination can change the structure of microbial communities and the literature used by Will and Suter (1994) to establish the benchmarks for COPECs showed that metal contamination affected $\mathrm{C}$ mineralization, $\mathrm{N}$ transformation, and microbial enzyme activities.

The effects of contaminants on plant communities is of similar ecosystem importance because the production of plant matter influences the cycling of carbon and is a primary source of organic carbon for soils and aquatic ecosystems. The concentration of $\mathrm{Al}, \mathrm{B}, \mathrm{Cd}, \mathrm{Mn}$, and $\mathrm{Zn}$ in aspen leaves and aspen leaf miner larvae indicates not only $\mathrm{C}$ inputs were impacted but that foodchain transfer and biomagnification of metal contamination is also possible.

Arsenic accumulation in bear hair and $\mathrm{Cd}$ in fish liver suggest a potential for transfer of mine waste contaminants to top predators and indicate that environmental degradation has occurred in both aquatic and terrestrial ecosystems (Dallinger 1987, Hodson 1990). Arsenic, which was found to accumulate in the hair of bears in the vicinity of the Alder Mine, is a useful indicator of exposure to arsenic over the preceding 6-12 months (DHHS 2000). We detected an average concentration in the exposed bears equal to $0.89 \mathrm{mg} \mathrm{Kg}^{-1}$, which was 18 times the average for As in the hair of the reference bears $\left(0.05 \mathrm{mg} \mathrm{Kg}^{-1}\right)$. One hair sample from the contaminated site had As in their hair at $1.14 \mathrm{mg} \mathrm{Kg}^{-1}$. Although the pattern of As metabolism in bears is unknown and may not be similar to humans, the normal level of As in human hair is $<1 \mathrm{mg} \mathrm{Kg}^{-1}$ (DHHS 2000). When elevated levels of arsenic are detected, it shows that there has been exposure, but unless more is known about the timing and duration of exposure and the species specific 
response to As, it is not possible to calculate risk of carcinogenicity among bears or other exposed animals.

This study also showed that community level effects were caused by contaminated water and sediments form abandoned mines based on the observation that abundance and diversity of benthic invertebrates were reduced in Alder Creek below Alder Mine compared to the unimpacted reference sites in Poor man Creek. In the reference stream community, a few species made up the bulk of the community and there was a long tail of rare or infrequently encountered species. When biomass, a measure of carbon storage, is considered as the indicator of ecosystem function, it is the relatively small set of abundant species that are functionally important because they are doing the bulk of nutrient uptake and transfer. The numerous other species that make up a small percentage of the biomass are functionally equivalent to the dominant species but have different environmental requirements and tolerances (Walker et al. 1999). It is the minor species that provide ecosystems with resiliency by maintaining ecosystem function under changing environmental conditions. When conditions change following contamination, metals sensitive species are replaced by metals-tolerant species, which reduces diversity and abundance, lowers resiliency and affects an ecosystem's ability to maintain productivity should there be further conditions.

Benthic invertebrates are also valued for their community level properties because they have a naturally wide distribution, high abundance, and taxonomic diversity, which makes them good indicators of habitat quality. Also, because benthic invertebrates vary in sensitivity to contaminants, relative immobility, and because they are long-lived, they integrate spatial and temporal variations in exposure to contaminants. The structure of benthic communities can, therefore, be used to indicate whether the criteria necessary for a health biological community have been met. As a result, various types of organisms have been found to be tolerant to metals and a population of tolerant organisms combined with an absence of intolerant organisms is an indication of pollution.

At the population level, one member of the benthic community was studied and we found that the live body weights per 100 caddisfly larvae (Ecclesiomyia spp) downstream from the mine sites were approximately 48\% lower than larvae sampled upstream. For both up- and downstream sample sets, the larvae were comprised mostly of third and forth instar stages, which is consistent with the characterization that Ecclesiomyia spp has a slow-seasonal life-style characterized by distinct changes of larval size with time (Merritt and Cummins 1996, Irons 1987). The observation that larvae in the Methow River downstream from the mines is dominated by stage-three instars and that upriver most larvae were stage-four instars suggests development of the former may be delayed by as much as one-month when compared to life-history histograms for Ecclesiomyia spp and other slow-seasonal caddisflies (Merrit and Cummins 1996, Irons 1987). The inhibition of growth suggests either a diversion of energy from growth to tissue repair or mine waste contaminants place physiological limits on the rate of food conversion into usable energy.

We also observed reduced growth and increased mortality among individual trout in pens downstream from the mines compared to upstream controls. The source of toxic mine waste contaminants could be due either to episodic exposures to contaminants that were not detected during sampling and analysis of water for dissolved metals (Marr et al. 1995, Hanson 2002) or to dietary metals (Mount et al. 1994, Dallinger 1985). It is not obvious which of these two pathways is responsible for the effects seen but exposure to sediments that are known to be enriched with metals from the abandoned mines is a likely cause rather than dissolved metals, which were less than the limits of detection during the study period. 
Toxins are known to induce biochemical changes in the liver with more drastic systemic dysfunctions following saturation of the liver's ability to sequester the toxins (Bunton 1994) and alterations in blood glucose and liver glycogen constitute a typical stress response in fish (Gill and Pant 1981). Monitoring of the appropriate biochemical parameter in the liver is useful, therefore, for the detection of toxicity at an early stage of exposure. In the mitochondria, the decreased number and increased size of matrical granules indicate a toxin-induced change has occurred (Phillips 1987). The electron dense granules are accumulations of divalent cations (Peachy 1964, Walton 1967). Metal uptake by mitochondria is by active transport (Walton 1967) and it appears that divalent cations are deposited on or in pre-existing granules in exchange for calcium (Brdiczka and Barnard 1980). The appearance of electron-dense matrical granules, when compared to in vitro toxicity data from a variety of other bioassays, suggests the decreased number and increased size of matrical granules is a good indicator of metal toxicity for several fish and invertebrate species (Argese 1996).

Glycogen bodies in the cytosol and nuclei of hepatocytes also are indicators of toxininduced metabolic disease and are sometimes associated with Wilson's Disease, a genetic disorder of copper metabolism in humans (Phillips 1987, Goldblatt and Cunning 1984, Ostrakovitch 2002). The accumulation of glycogen inclusions in hepatocytes that displaces the nucleus to the periphery of the cell is pathognomic of type IV glycogen storage disease (GSD IV, Anderson's disease, amylopectinosis) in humans (Sherlock and Dooley 1997, Ishak and Sharp 1979). GSD IV is caused by an enzyme deficiency that results in the synthesis of an abnormal glucogen molecule having decreased branch points and increased chain length. Biochemically the unbranched glycogen, similar to amylopectin, becomes less soluble and glycogenolysis is reduced (Goodman and Ishak 1999). The abnormal glucogen structure is due to a deficiency of the branching enzyme amylo-1,4,1,6 transglucosidase (Sherlock and Dooley1997, Ishak and Sharp 1979).

While GSD may be an inherited metabolic condition it may also be a part of a toxic process (Goodman and Ishak 1999). With the exception of $\mathrm{Cu}$ and $\mathrm{Zn}$, the metals $\mathrm{Pb}, \mathrm{Hg}, \mathrm{Cd}, \mathrm{Cr}$, Mn, Mo, Ni and Co caused hepatic glycogenolysis (Goodman and Ishak 1999, Gill and Pant 1981). In our study, the occurrence of glycogen inclusions in the liver suggest that $\mathrm{Cu}$ may be eliciting biochemical stress in exposed fish and that elevated concentrations of $\mathrm{Cu}$ in sediments downstream from the abandoned mines is resulting a metabolic disorder in which food is being converted first into glucose then glycogen and stored in the liver but the glycogen is not being converted back normally into glucose for distribution to the tissues. Decreased energy flow explains why reduced growth and increased mortality is common among individuals with GSD (Sherlock and Dooley1997, Ishak and Sharp 1979) 


\section{CONCLUSION}

This study showed that the effects of mine waste contaminants can be expressed at all levels of organization, from the molecular to ecosystem-level, and that there are potential indicators at each level. The mechanistic linkages that integrate responses across levels of organization appears to be related to the disruption of energy exchange among cells, tissues, organisms, populations, communities and the environment. The aggregate effects of mine waste contamination on subcellular organelles suggest conditions similar to Wilson's or glycogen storage disease is occurring at the tissue level where the rate of food conversion into usable energy has been reduced. Reduced growth among individual fish and among populations of caddisfly larvae exposed to contaminated sediments appears to be the logical result of reduced energy conversion. The diversion of energy as a result of the physiological response to mine waste contaminants reduces competition among metals intolerant species and results in changes in community structure. When changes in community structure, and the functional property of a community is altered, then ecosystem function is also effected. 


\section{REFERENCES}

Argese, E., C. Bettiol, P. Miana, L. Iuzzolino, and G. Giurin. 1996. Submitochondrial particles as in vitro biosensors of heavy metal toxicity. Journal of Aquatic Ecosystem Health. 5:125-134.

Bunton, T.E. and J.M. Frazier. 1994. Extrahepatic tissue copper concentrations in white perch with hepatic copper storage. Journal of Fish Biology. 45(4):627-640.

Clements, W.H. 2000. Integrating effects of contaminants across levels of biological organization: an overview. Journal of Aquatic Ecosystem Stress and Recovery. 7:113-16.

Dallinger, R. and H. Kautzky. 1985. The importance of contaminated food for the uptake of heavy metals by rainbow trout (Salmo gairdneri): a field study. Oewcologia 67:82-89.

DHHS, U.S.: 2000. Toxicological Profile for Arsenic (Update). Agency for Toxic Substances and Disease Registry (ATSDR). Atlanta, Georgia.

Gill, T.S. and J.C. Pant. 1981. Toxicity of nickel to the fish Puntus conchonius (Ham.) and its effects on blood glucose and liver glycogen. Comp. Physiol. Ecol. 6(2):99-102.

Glodblatt, P.J. and W.T. Gunning. 1984. Ultrastructure of the liver and biliary tract in health and disease. Annals of Clinical and Laboratory Science. 14(2):159-167.

Goodman, Z.D. and K.G. Ishak, 1999. Hepatic histopathology: metabolic diseases. Schiff's Diseases of the Liver. (E.R. Schiff, M.F. Sorrell, and W.C. Maddrey). Lippincott-Raven, New York.

Hanson, J.A., P.G. Welsh, J. Lipton, and M.J. Suedkamp. 2002. The effects of long-term cadmium exposure on the grouwth and survival of juvenile bull trout (Salvelinus confluentus). Aquatic Toxicology. 58:163-174.

Hauer, F.R. and G.A. Lamberti. 1996. Methods in Stream Ecology. Academic Press. San Diego.

Hodson, P.V. 1990. Indicators of ecosystem health at the species level and the example of selenium effects on fish. Enviromental Monitoring and Assessment 15:241-254.

Hopenhayn-Rich, C., S.R. Browning, I.Hertz-Picciotto, C. Ferreccio, C. Peralta, and H. Gibb. 2000. Chronic arsenic exposure and risk of infant mortality in two areas of chile. Environmental Health Perspectives. 108(7):667-673.

Hull, R.N. and G. W. SuterII. 194. Toxicological benchmarks for screening potential contaminants of concern for effects on sediment-associated biota: 1994 Revision, ES/ER/TM-95/R1, Oak Ridge ational Laboratory, Oak Ridge, TN.

Irons, J.G. 1987. Life history patterns and trophic ecology of Trichoptera in two Alaskan (U.S.A.) subarctic streams. Can. J. Zoology. 66:1258-1265.

Ishak, K.G. and H.L. Sharp. 1987. Metabolic errors and liver disease. Pathology of the Liver. (R.N.M. MacSween, P.P. Anthony, and P.J. Scheuer, eds.). Churchill Livingstone, New York. 
Marr, J.C.A. H.L. Bergman, M. Parker, J. Lipton, D. Cacela, W. Erikson, and G.R. Phillips. 1995.

Relative sensitivity of brown and rainbow trout to pulsed exposures of an acutely lethal mixture of metals typical of the Clark Fork River, Montana. Can. J./ Fish. Aquat. Sci. 52:2005-2015.

Merritt, R. W., and K. W. Cummins, eds. 1996. An Introduction to the Aquatic Insects. Third Edition. Kendall/Hunt, Dubuque.

Morgenstern, H. 1995. Ecologic studies in epidemiology: concepts, principles, and methods. Annual Review of Public Health. 16:61-81.

Mount, D.R. A. K. Barth, T. D. Garrison, K. A. Barten, and J. R. Hockett. 1994. Dietary and waterborne exposure of rainbow trout (Oncorynchus mykiss) to copper, cadmium, lead and zinc using a live diet. Environmental Toxicology and Chemistry. 13(12):2031-2041.

Opresko, D.M., B.E. Sample, and G.W. Suter II. 1994. Toxicological benchmarks for wildlife, ES/ER/TM86/R1, Oak Ridge Natinal Laboratory, Oak Ridge, TN.

Ostrakovitch, E.A., M.R. Lordnejad, F. Schliess, H.Sies, and L.O. Klotz. 2002. Copper ions strongly activate the Phosphoinositide-3kinase/Akt pathway independent of the generation of reactive oxygen species.

Peachy, L.D. 1964. Electron microscopic observations on the accumulation of divalent cations in intramitochondrial granules. The Journal of Cell Biology. 20:95-109.

Phillips, M.J., S. Poucell, J. Patterson, and P. Valencia. 1987. The Liver: An Atlas and Text of Ultrastructural Pathology. Raven Press. New York.

Selvin, H.C. 1958. Durkheim's "suicide" and problems of emperical research. American Journal of Sociology. 63:607-619.

Sherlock, S, and J. Dooley. 1997. Diseases of the Liver and Biliary System, $10^{\text {th }}$ edition. Blackwell Science, Oxford.

Suter, G.W. (II). 1990. Endpoints for regional ecological risk assessments. Environmental Management. 14(1):9-23.

Suter, G.W. and J.B. Mabrey. 1994. Toxicological benchmarks for screening potential contaminants of concern for effects on aquatic biotic: 1994 revision, ES/ER/TM-96/R1, Oak Ridge National Laboratory, Oak Ridge, TN.

Timmermans, K.R., B. Van Hattum, M.H.S. Draak, and C. Davids. 1989. Trace metals in a littoral foodweb: concentrations in organisms, sediment and water. The Science of the Total Environment, 87/88:477-494.

Walker, B., A. Kinzig, and J. Langridge. 1999. Plant attribute diversity, resilience, and ecosystem function: the nature and significance of dominant and minor species. Ecosystems. 2:95-113.

Walton, J.R. 1973. Granules containing lead in isolated mitochondria. Nature. 243(5402):100-101. 
WSCC (Washington State Conservation Commission). 2002. Salmon and Steelhead Habitat Limiting Factors Water Resource Inventory. Area 48. Methow Watershed.

Will, M.E. and G.W. Suter II. 1994. Toxicological benchmarks for screening potential contaminants of concern for effects on soil and litter invertebrates and heterotrophic processes, ES/ER/TM-126, Oak Ridge National Laboratory, Oak Ridge, TN.

Woodward, D.F. A.M. Farag, H.L. Bergman, A.J. DeLonay, E.E. Little, C.E. Smith, and F.T. Barrows. Metals-contaminated benthic invertebrates in the Clark Fork River, Montana: effects ib age-0 brown trout and rainbow trout. Can. J. Fish. Aquat. Sci., 52:1994-2004. 


\section{EXPECTED ACCOMPLISHMENTS FOR 3/15/2002 - 3/14/2003 PERFORMANCE PERIOD}

1. Complete preparation and examination of gill, liver, kidney and small intestine tissue sections stained with H\&E, Mallory's and Mallory-Parker stains using light microscopy.

2. Complete preparation and examination of gill, liver, kidney and small intestine tissue sections from trout using transmission electron microscopy. Midgut epithelial cells will also be examined for evidence of heavy metal exposure in aquatic and terrestrial invertebrate larva.

3. Use transmission electron microscopy and energy dispersive x-ray analysis to identify the heavy metal composition of the submitochondrial granules in trout and invertebrate larva. Relate metals affecting mitochondrial function to tissue, organ, individual, population, community and ecosystem level effects of heavy metal pollution.

4. Recommend restoration guidelines and biological goals that target identified pathways and processes of metal pollution affecting salmon habitat in the Methow basin.

5. Present paper, "Contamination from Abandoned Mines and its Impact on Organisms in the Methow River, Washington, USA" at the International Conference "Disturbed Landscapes" in September 2002 at the Brandenburg University of Technology, Research Center for Mining Landscapes, Cottbus, Germany.

6. Submit peer review journal publications.

7. Analyze data and format for submission to Web-Archive (e.g., WDOE and BPA)

8. Prepare final Report. Include bibliography of reports, posters, and presentations 